\title{
CYTOGENETIC CHARACTERIZATION OF Ameivula ocellifera (SPIX, 1825) (SQUAMATA, TEIIDAE) FROM THE BRAZILIAN NORTHEAST
}

\author{
CARACTERIZAÇÃO CITOGENÉTICA DE Ameivula ocellifera (SPIX, 1825) \\ (SQUAMATA, TEIIDAE) DO NORDESTE BRASILEIRO
}

\author{
Marcelo João da SILVA ${ }^{\mathbf{1}}$; Flávia Manoela Galvão CIPRIANO ${ }^{\mathbf{1}}$; Ana Paula de Araújo VIEIRA ${ }^{\mathbf{1}}$; \\ Maria Rita dos Santos CÂNDIDO' ${ }^{1}$; Tamaris Gimenez PINHEIRO'; \\ Edson Lourenço da SILVA ${ }^{2 *}$ \\ 1. Federal University of Piauí, Senador Helvídio Nunes de Barros Campus (UFPI), Picos, Piauí, Brazil; 2. Biology Laboratory, Federal \\ Institute of Education, Science and Technology of Piauí (IFPI), Picos, Piauí, Brazil. \\ *ed.loren@ifpi.edu.br.
}

\begin{abstract}
Ameivula is as a new genus of Teiidae family that emerged after extensive revision of species that comprised the former complex of species called Cnemidophorus group. Its species has a wide distribution from the northeast of Brazil to northern Argentina. Cytogenetic studies in the Teiidae family have shown that karyotypical data are important tools in phylogenetic and systematic studies within this group allowing to determine the position of species in the family. Thus, this study aimed to describe the karyotype of Ameivula ocellifera (Spix, 1825) from Picos, Piauí state in the Brazilian Northeast. Specimens were collected from August 2014 to October 2015 using interception traps and pitfalls, mounted randomly along the Caatinga area. The animals were collected and transported to Federal Institute of Piauí, campus Picos, where was carried out all laboratory procedures. Individuals analyzed showed a diploid number of $2 n=50$ for both sexes, with karyotype composed by 30 macrochromosomes and 20 microchromosomes of telocentric and subtelocentric types. There were no heteromorphic sex chromosomes in the studied specimens. C-band technique evidenced the heterochromatic blocks in pericentromeric and telomeric regions of chromosomes. The nucleolar organizing regions appeared as a simple unit located at the terminal portion of the long arm of chromosomal pair number 5. The chromosomal characteristics of A. ocellifera analyzed do not show divergences regarding individuals from other regions. However, the nucleolar organizing regions seems to be a good chromosomal marker that permits to distinguish the species already studied.
\end{abstract}

KEYWORDS. Ameivula ocellifera. C Banding. Cytogenetic markers. Karyotype. NOR.

\section{INTRDUCTION}

The Teiidae family is a group of lizards comprising 160 species distributed in three subfamilies: Teiinae integrates the genera Ameiva Meyer 1795, Ameivula (Spix, 1825), Aurivela (Bell, 1843), Aspidoscelis Fitzinger 1843, Contomastix (Dumésil \& Bibron, 1839), Cnemidophorus Wagler 1830, Dicrodon Duméril \& Bibron 1839, Holcosus (Cope, 1862) Kentropyx Spix 1825, Medopheos (Bocourt, 1874) and Teius Merrem 1820; Tupinambinae includes the genera Crocodilurus Spix 1825, Dracaena Daudin 1802, Salvator (Dumésil \& Bibron, 1839) and Tupinambis (Daudin, 1802); and finally Callopistinae with only Callopistes Gravenhorst 1838 (HARVEY; UGUETO; GUTBERLET, 2012; UETZ, 2019).

The Ameivula genus emerged from extensive systematic revisions in Teiidae family totaling 11 valid species of small animals (UETZ, 2019). Its species are widely distributed throughout Brazil and can be found from the Brazilian
Northeast to the north of Argentina (VANZOLINI; RAMOS-COSTA; VITT, 1980). In Brazil, this lizard occurs in several environments, such as the Caatinga (VITT, 1983; MENEZES et al. 2011), Cerrado (MESQUITA; COLLI, 2003), and restinga of Atlantic Forest (SANTANA et al. 2010). Ameivula ocellifera (Spix, 1825) is a species of active foraging habit, with ecological and morphological characteristics identical to other species of the genus (SILVA; ARAÚJO, 2005).

In the '70s Teiidae was divided into three groups based on the chromosomal characteristics of its members: (1) a group consisting of the genera Dracaena, Callopistes, Crocodilurus and Tupinambis, with a diploid number of $2 \mathrm{n}=34-38$, divided into five to six pairs of metacentric macrochromosomes and one satellite in pair 2; (2) a group formed by the genera Ameiva, Dicrodon, Kentropyx, Teius, and Cnemidophorus of which of the latter, some species became Ameivula, with diploid number $2 \mathrm{n}=46-56$ with many acrocentric chromosomes; and (3) a group with the microteiids 
with a diploid number of $2 \mathrm{n}=46$ (GORMAN, 1970).

The ancient karyotype of Teiidae would have originated from centric fission of macrochromosomes of an ancestral karyotype of Tupinambinae with $2 \mathrm{n}=50$ (GORMAN, 1973). Additionally, pericentric inversions, fusions and fissions may have been responsible for the karyotypic diversification of some of the species, e.g., those belonging Cnemidophorus genus, in which chromosome numbers in diploid species vary between $2 \mathrm{n}=46$ and 52 . In triploid species, they vary from $3 n=69$ to 71 , and it is of $4 n=92$ chromosomes in tetraploid species (GORMAN, 1970; PECCININI-SEALE, 1981, 1989).

Thus, considering the karyotype variation already defined for different genera and species of the Teiidae family, this study aimed to describe the karyotype of a population of Ameivula ocellifera, looking for genetic patterns that can be used as a tool to establish differences between species.

\section{MATERIAL AND METHODS}

The specimens were collected from August 2014 to October 2015, in areas of Caatinga in the city of Picos, state of Piauí, Brazil. The collection used pitfalls mounted in places where the presence of lizards was observed. The traps were checked three times a day and the captured animals were collected to prevent them from dying due to excessive heat.

Thus, the collected animals were taken to the Biology Laboratory of the Federal Institute of
Piauí, campus Picos, where all procedures were performed for the obtention of cytogenetic material, cataloguing, recording and subsequent fixation and preservation. All under license of collection and processing of the animals, issued by the Chico Mendes Institute for Biodiversity Conservation ICMBIO through the SISBIO platform, number: 47710-1.

Chromosomal preparations were obtained through the air-drying method as described by Bertollo, Takahashi and Moreira-Filho (1978). Cbanding (Sumner, 1972) was used to visualize Heterochromatin regions and silver nitrate staining to detect NORs, according to the procedure described by Howel, Black, (1980).

Chromosomes were observed using a microscope coupled to a camera, and the best images captured. The chromosomal nomenclature was based on the system of Levan, Fredga and Sandberg (1964) taking into account only macrochromosomes (M) and microchromosomes (m).

\section{RESULTS}

Cytogenetic analyses were performed on three males and four females of Ameivula ocellifera. The individuals analyzed showed a diploid number of $2 \mathrm{n}=50$ for both sexes, with a karyotype composed of 30 macrochromosomes and 20 microchromosomes of telocentric and subtelocentric types (Figure 1). There were no heteromorphic sex chromosomes observed in the specimens studied. (a)

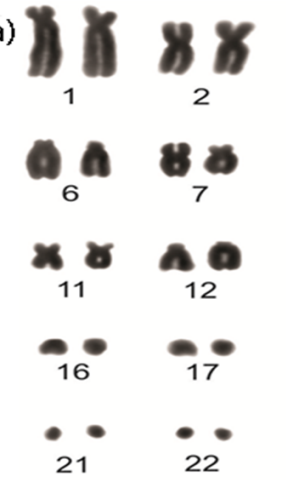

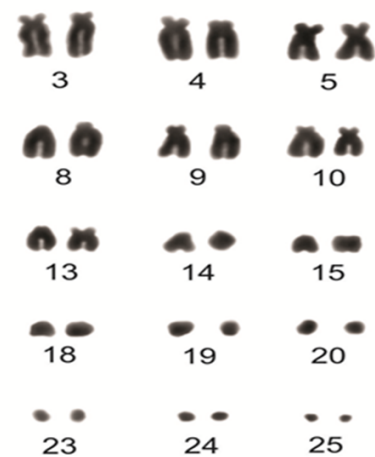

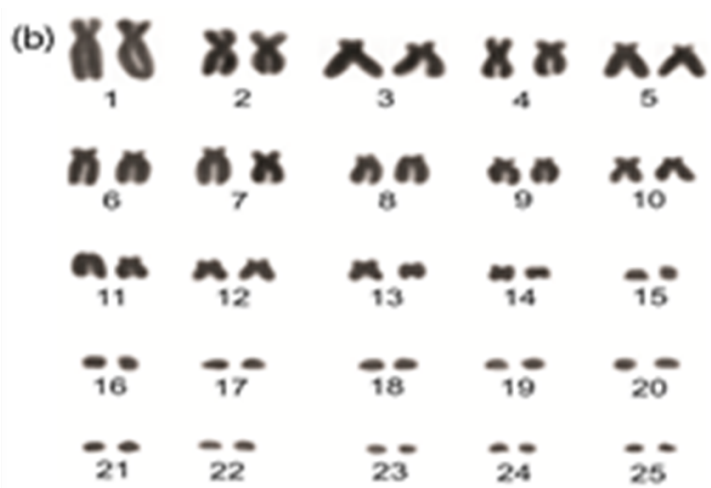

Figure 1. Karyotype of $A$. ocellifera in conventional staining with Giemsa showing $2 \mathrm{n}=50$ chromosomes.

a) Male individual. b) Female individual.

The C-banding technique showed blocks of heterochromatin in the pericentromeric and telomeric regions in both arms in several pairs of chromosomes of both sexes (Figure 2).
The nucleolar organizing region is present in the terminal portion of the long arm of number 5 pair in individuals of both sexes (Figure 3). It was not possible to observe secondary constriction in the analyzed metaphases. 


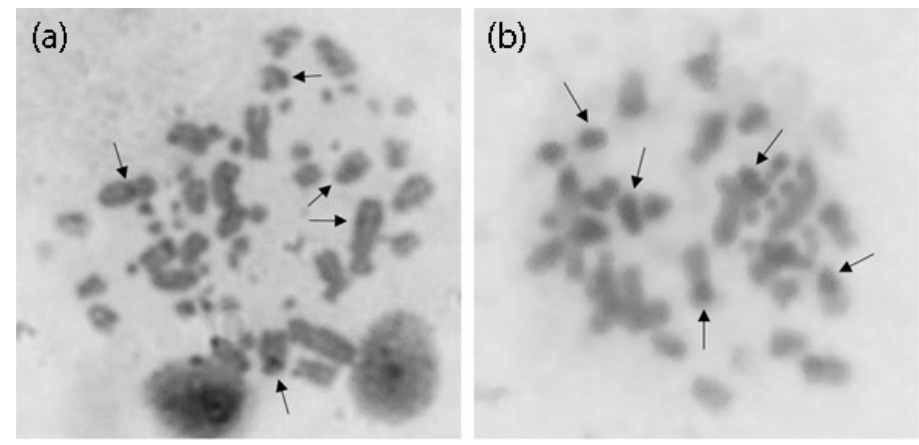

Figure 2. Metaphases of $A$. ocellifera showing the constitutive heterochromatin. a) Male individual. b) Female individual. The arrows indicate the most visible heterochromatic blocks.

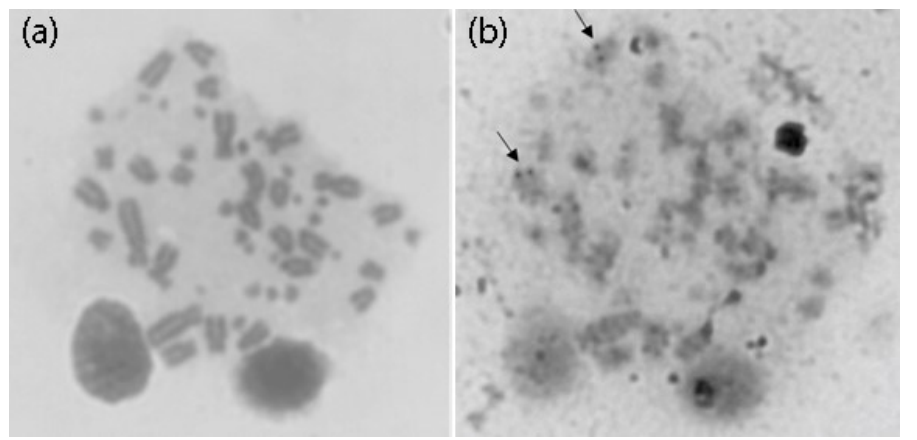

Figure 3. Metaphase of $A$. ocellifera. a) conventional staining with Giemsa. b) Impregnation with Silver Nitrate showing in the arrows the chromosomal pairs carrying the nucleolar organizing regions.

\section{DISCUSSION}

In recent years, the Teiidae family and its genera have undergone major changes that have led to the repositioning of species into complexes and the creation of new genera. Ameivula is a new genus that accommodates the species that belonged to the former group Cnemidophorus ocellifera. The complexity in the precise determination involving the species Cnemidophorus ocellifera arouse works based on phylogenetic evidence and molecular data. These works positioned these species in the new genus Ameivula, even though the latter having many features shared with the Ameiva species (GIUGLIANO; CONTEL; COLLI, 2006).

The diploid number of $2 \mathrm{n}=50$ that includes biarmed chromosomes observed in Ameivula ocellifera in this study remains unaltered despite its wide geographic distribution. This fact also corroborates the studies in individuals also attributed to the Northeast and Southeast of Brazil (SANTOS et al. 2007). However, there is a reduction in the karyotype of Ameivula nativo (ROCHA; BERGALLO; PECCININI-SEALE, 1997) that have $2 \mathrm{n}=48$ (ROCHA; BERGALLO; PECCININI-SEALE. 1997) and Ameivula littoralis
(ROCHA; ARAÚJO; VRCIBRADIC; COSTA, 2000 ) with $2 \mathrm{n}=46$, and an $\mathrm{XY}$ sex chromosome system (PECCININI-SEALE et al. 2004) (Tab. 1). Signs of chromosome rearrangements in the species of Ameivula are evident when comparing the $A$. littoralis karyotype from the Brazilian Southeast, with other South American species (PECCININISEALE et al. 2004). According to the latter authors, the decrease in diploid number observed can be attributed to centric fusions of microchromosomes. In addition, pericentric inversions in the first and second pair of chromosomes occurred in $A$. littoralis, making these pairs of the submetacentric type.

The constitutive heterochromatin patterns observed in Ameivula ocellifera shows pericentromeric and telomeric regions with numerous blocks of heterochromatin in the two arms of several pairs of chromosomes (Table 1). This is very similar among the species of the Teiidae family such as Ameiva ameiva (LINNAEUS, 1758) and Kentropyx paulensis (BOETTGER, 1893) (SANTOS et al. 2007). The constitutive heterochromatin is restricted to the telomeric and centromeric region in Ameiva and Cnemidophorus species from other regions of the 
country. In specimens of these regions, the microchromosomes were almost entirely heterochromatic, and this fact appears being common among those related groups.

Table 1. Chromosome data available for Brazilian Ameivula species.

\begin{tabular}{|c|c|c|c|c|c|}
\hline Specie & $\begin{array}{l}\text { Chromosomal } \\
\text { number and } \\
\text { karyotypic formulae }\end{array}$ & NOR & $\begin{array}{l}\text { Constitutive } \\
\text { heterochromatin }\end{array}$ & $\begin{array}{l}\text { Brazilian } \\
\text { region }\end{array}$ & Reference \\
\hline \multirow{2}{*}{$\begin{array}{l}\text { Ameivula ocellifera } \\
\text { (Spix, 1825) }\end{array}$} & $\begin{array}{l}50 \text {. Gradual series of } \\
\text { acrocentric } \\
\text { chromosomes }\end{array}$ & \multirow{2}{*}{$\begin{array}{l}\text { Terminal, } \\
\text { long arm pair } \\
5\end{array}$} & \multirow{3}{*}{$\begin{array}{l}\text { Centromeric and } \\
\text { Telomeric } \\
\text { regions }\end{array}$} & $\begin{array}{l}\text { Northeast } \\
\text { Southeast }\end{array}$ & $\begin{array}{l}\text { Santos et al. } \\
(2007)\end{array}$ \\
\hline & $\begin{array}{l}50.24 \text { metacentric/ } \\
\text { telocentric; } 26 \mathrm{~m} \\
\text { subtelocentric }\end{array}$ & & & Northeast & Present paper \\
\hline $\begin{array}{l}\text { Ameivula littoralis } \\
\text { (ROCHA, ARAÚJO, } \\
\text { VRCIBRADIC; } \\
\text { COSTA, 2000) }\end{array}$ & $\begin{array}{l}\text { 46. } 5 \text { submetacentric; } \\
41 \text { telocentric/ } \\
\text { subtelocentric } \\
(\mathrm{XX} ; \mathrm{XY})\end{array}$ & $\begin{array}{l}\text { Terminal, } \\
\text { long arm pair } \\
8\end{array}$ & & Southeast & $\begin{array}{l}\text { Peccinini- } \\
\text { Seale et al. } \\
(2004)\end{array}$ \\
\hline $\begin{array}{l}\text { Ameivula nativo } \\
\text { (ROCHA, } \\
\text { BERGALLO; } \\
\text { PECCININI-SEALE, } \\
\text { 1997) }\end{array}$ & $\begin{array}{l}50.5 \text { submetacentric; } \\
19 \text { telocentric/ } \\
\text { subtelocentric; } 24 \\
\text { microchromosomes }\end{array}$ & $\begin{array}{l}\text { Multiple } \\
\text { undefined } \\
\text { pairs }\end{array}$ & & Southeast & $\begin{array}{l}\text { Rocha, } \\
\text { Bergallo and } \\
\text { Peccinini- } \\
\text { Seale (1997) }\end{array}$ \\
\hline
\end{tabular}

Regarding the NORs, the number and position seem remaining conserved in Ameivula ocellifera in accordance with other populations previously analyzed (Table 1). The exception is the absence of size polymorphism as those observed by Santos et al. (2007). It was also detected in the congeneric species Ameivula littoralis a single pair carrying the NOR (PECCININI-SEALE et al. 2004). However, in Ameivula nativo, multiple NOR were noticed in a different chromosome pair (ROCHA BERGALLO; PECCININI-SEALE, 1997). This differentiation maybe due rearrangements involving the nucleolar organizer regions among the Ameivula species from Brazil.
In this way, despite the stability in the diploid number proven with this study, the NORs pattern is a useful tool to establish differences among the Ameivula species, contributing to correct identification of regional forms of these lizards.

\section{ACKNOWLEDGMENTS}

The authors are grateful Instituto Federal do Piauí (PROAGRUPAR-INFRA 033/2014) for logistic and financial support and to the anonymous reviewers for suggestions to our manuscript.

RESUMO: Ameivula é um novo gênero da família Teiidae que surgiu após extensa revisão de espécies que compuseram o antigo complexo de espécies chamado grupo Cnemidophorus. Suas espécies têm uma ampla distribuição do nordeste do Brasil ao norte da Argentina. Estudos citogenéticos na família Teiidae mostraram que os dados cariotípicos são ferramentas importantes em estudos filogenéticos e sistemáticos dentro deste grupo, permitindo determinar a posição das espécies na família. Assim, este estudo tem como objetivo descrever o cariótipo de Ameivula ocellifera (Spix, 1825) de Picos, no nordeste brasileiro. Os espécimes foram coletados de agosto de 2014 a outubro de 2015 utilizando armadilhas de interceptação e armadilhas, montadas aleatoriamente ao longo da área da Caatinga. Os animais foram coletados e transportados para o Instituto Federal do Piauí, campus Picos, onde foram realizados todos os procedimentos laboratoriais. Os indivíduos analisados apresentaram um número diploide de $2 \mathrm{n}=50$ para ambos os sexos, com cariótipo composto por 30 macrocromossomos e 20 microcromossomos dos tipos telocêntrico e subtelocêntrico. Não houve cromossomos 
sexuais heteromórficos nos espécimes estudados. A técnica da banda $\mathrm{C}$ evidenciou os blocos heterocromáticos nas regiões pericentroméricas e teloméricas dos cromossomos. As regiões organizadoras de nucléolos apareceram como uma unidade simples localizada na porção terminal do braço longo do par cromossômico número 5. As características cromossômicas de $A$. ocellifera analisadas não mostram divergências em relação a indivíduos de outras regiões. No entanto, as regiões organizadoras de nucléolos parecem ser um bom marcador cromossômico que permite distinguir as espécies já estudadas.

RON.

PALAVRAS-CHAVE. Ameivula ocellifera. Bandamento C. Marcadores citogenéticos. Cariótipo.

\section{REFERENCES}

BERTOLLO, L. A. C.; TAKAHASHI, C. S.; MOREIRA-FILHO, O. Cytotaxonomic considerations on Hoplias lacerdae (Pisces, Erythrinidae). Brazilian Journal of Genetics, v. 1, p. 103-120, 1978.

GIUGLIANO, L. G.; CONTEL, E. P. B.; COLLI, G. R. Genetic variability and phylogenetic relationships of Cnemidophorus parecis (Squamata, Teiidae) from Cerrado isolates in southwestern Amazonia. Biochem. Journal of Ecosystem and Ecography, v. 34, p. 383-391, 2006. https://doi.org/10.1016/j.bse.2005.12.007

GORMAN, G. C. Chromosomes and the systematics of the Family Teiidae (Sauria, Reptilia). Copeia, v. 2, p. 230-245, 1970.

GORMAN, G. C. The chromosomes of the Reptilia, a cytotaxonomic interpretation. In Cyotaxonomy and vertebrate evolution (ed. A. B. Chiarelli and Capanna), pp. 349-424. Academic Press, New York, 1973. https://doi.org/10.2307/1441645

HARVEY, B.; UGUETO, G. N.; GUTBERLET, R. L. Review of Teiid Morphology with a Revised Taxonomy and Phylogeny of the Teiidae (Lepidosauria: Squamata). Zootaxa, v. 3459, 1-156, 2012.

https://doi.org/10.11646/zootaxa.3459.1.1

HOWELL, W. M.; BLACK, D. A. Controlled silver staining of the nucleolus organizer regions with a protective colloidal developer: a 1-step method. Experientia, v. 36, p. 1014-1015, 1980.

https://doi.org/10.1007/BF01953855

LEVAN, A.; FREDGA, K.; SANDBERG, A. A. Nomenclature of centromeric position on chromosomes. Hereditas, v. 52, p. 201-220, 1964. https://doi.org/10.1111/j.1601-5223.1964.tb01953.x

MENEZES, V. A.; VAN LUYS, M.; FONTES, A. F.; ROCHA, C. F. D. Living in a caatinga-rocky field transitional habitat: ecological aspects of the whiptail lizard Cnemidophorus ocellifer (Teiidae) in northeastern Brazil. Zoologia, v. 28, p. 8-16, 2011. https://doi.org/10.1590/S1984-46702011000100002

MESQUITA, D. O.; COLLI, G. R. The ecology of Cnemidophorus ocellifer (Squamata, Teiidae) in a Neotropical Savanna. Journal of Herpetology, v. 37, p. 498-509, 2003. https://doi.org/10.1670/179-02A

PECCININI-SEALLE, D. New developments in vertebrate cytotaxonomy. IV. Cytogenetic studies in reptiles. Genetica, v. 56, p.123-148, 1981. https://doi.org/10.1007/BF00055413

PECCININI-SEALLE, D. Genetic studies on bisexual and unisexual populations of amazonian Cnemidophorus. In Evolution and ecology of unisexual vertebrates (ed. R. M. Dawley and J. P. Bogart), pp. 241-251. New York State University Press, Albany, 1989.

PECCININI-SEALE, D.; ROCHA, C. F. D.; ALMEIDA, T. M. B.; ARAÚJO, A. F. B.; DE SENA, M. A. Cytogenetics of the Brazilian whiptail lizard Cnemidophorus littoralis (Teiidae) from a resting area (Barra de 
Maricá) in Southeastern Brazil. Brazilian Journal of Genetics, v. 64, p. 661-667, 2004. https://doi.org/10.1590/S1519-69842004000400014

ROCHA, C. F. D.; BERGALLO, H. G.; PECCININI-SEALE, D. Evidence of a unisexual population of the Brazilian whiptail lizard genus Cnemidophorus (Teiidae), with description of a new species. Herpetologica, v. 53, p. 374-382, 1997.

SANTANA, G. G.; VASCONCELLOS, A.; GADELHA, Y. E. A.; VIEIRA, W.L.S.; ALMEIDA, W.O.; NÓBREGA, R.P.; ALVES, R. R. N. Feeding habits, sexual dimorphism and size at maturity of the lizard Cnemidophorus ocellifer (Spix, 1825) (Teiidae) in a reforested restinga habitat in Northeastern Brazil.

Brazilian Journal of Biology, v. 70, p. 409-416, 2010. https://doi.org/10.1590/S1519-69842010005000006

SANTOS, R. M. L.; PELLEGRINO, K. C. M.; RODRIGUES, M. T.; YONENAGA-YASSUDA, Y. Banding patterns and chromosomal evolution in five species of neotropical Teiinae lizards (Squamata: Teiidae).

Genetica, v. 131, p. 231-240, 2007. https://doi.org/10.1007/s10709-006-9133-2

SILVA, V. N.; ARAÚJO, A. F. B. Ecologia de Lagartos Brasileiros. Technical Books, Rio de Janeiro, 2005.

SUMNER, A. T. A simple technique for demonstrating centromeric heterochromatin. Experimental Cell Research, v. 75, p. 304-306, 1972. https://doi.org/10.1016/0014-4827(72)90558-7

UETZ, P. (editor), The Reptile Database, http://www.reptile-database.org, accessed August 5, 2019.

VANZOLINI, P. E.; RAMOS-COSTA, A. M. M.; VITT, L. J. Répteis das caatingas. Academia Brasileira de Ciências, Rio de Janeiro, 1980. https://doi.org/10.5962/bhl.title.109659

VITT, L. J. Reproduction and sexual dimorphism in the tropical teiid lizard Cnemidophorus ocellifer. Copeia, v. 2, p. 359-366, 1983. https://doi.org/10.2307/1444378 